ZOOLOGIA 29 (3): 203-209, June, 2012

doi: $10.1590 /$ S1984-46702012000300003

\title{
Biodiversity of decapod crustaceans in the estuarine floodplain around the city of Belém (Pará) in Brazilian Amazonia
}

\author{
Danielle Viveiros Cavalcanteㄹ, Bianca Bentes da Silva ${ }^{1} \&$ Jussara Moretto Martinelli-Lemos ${ }^{1}$
}

${ }^{1}$ Laboratório de Biologia Pesqueira e Manejo dos Recursos Aquáticos, Grupo de Pesquisa em Ecologia de Crustáceos da
Amazônia, Instituto de Ciências Biológicas, Universidade Federal do Pará. Avenida Augusto Corrêa 1, 66075-110 Belém, PA, Brasil.
${ }^{2}$ Corresponding author. E-mail: jussara@ufpa.br

\begin{abstract}
The present study focused on the decapod fauna of the fluvial-estuarine environment of the Guajará Bay, in the Brazilian state of Pará, where specimens were collected monthly from six sites, from May 2006 to April 2007. A total of 6,793 specimens were captured, belonging to 11 species of crab and shrimp: eight palaemonids - Macrobrachium amazonicum (Heller, 1862), Macrobrachium surinamicum Holthuis, 1948, Macrobrachium carcinus (Linnaeus, 1758), Macrobrachium rosenbergii (De Man, 1879), Macrobrachium spp. 1-4 -, one portunid - Callinectes bocourti A. MilneEdwards, 1879 -, and two trichodactylids - Sylviocarcinus devileii H. Milne-Edwards, 1853 and Sylviocarcinus pictus (Milne-Edwards, 1853). While no significant differences were found in the ecological indices of diversity with respect to season, site, or trap size, a tendency for increased abundance and species richness was found during the dry season (August-November), in particular at some sites, apparently reflecting the influence of the estuary's saline wedge.
\end{abstract}

KEY WORDS. Decapoda; diversity; estuary.

Decapod crustaceans are important members of tropical benthic communities. In addition to their prominent ecological roles, many of the larger and more abundant species represent important food resources for man (HENDRICKX 1995). For instance, shrimp, prawns, and crabs are harvested using artisanal methods throughout the coastal zone of the Brazilian state of Pará, providing an important means of subsistence, in particular for low-income populations of estuarine areas. Faunal surveys of a given region are essential for the understanding of the local taxonomic diversity, especially in habitats affected by anthropogenic impacts, where the composition of communities may be significantly altered before it becomes fully documented.

A number of decapod species have been assigned to IUCN categories ranging from vulnerable to critically endangered (Magris et al. 2010). In most cases, this scenario is caused by the degradation or destruction of aquatic habitats through pollution, deforestation and silting, among other impacts (MAGALHÃES 1999).

Over the past twenty years a considerable body of studies has been published on Brazilian benthonic crustaceans, although freshwater species have received considerably less attention than their marine and estuarine counterparts (RocHA \& Bueno 2004). In addition, the decapods of the Brazilian state of Pará have been the subject of a relatively small proportion of these studies, despite the fact that the region they inhabit is a large aquatic ecosystems with an abundant and diverse decapod fauna (but see CinTra et al. 2003a, b, Viana et al. 2003, Barros \& Pimentel 2001, Silva et al. 2005, 2009, 2012, Nevis et al. 2009, Arruda \& Abrunhosa 2011, Bentes et al. 2011, Maciel et al.
2011, Oliveira et al. 2012a, b, Pires et al. 2008, Corrêa \& Martinelui 2009, Sімітн et al. 2010, 2011). The scarceness of information extends to the area surrounding Belém, the state capital and home to major scientific research institutions.

The Belém region (Fig. 1) is characterized by a highly dynamic estuarine system that is heavily influenced by tide action (semi-diurnal oceanic tides), and has suffered considerable anthropogenic impacts. According to Bentes et al. 2011, the high turbidity is one of the main characteristics of this estuarine. It results from a large amount of suspended matter, which gives the water a muddy, greenish-yellow appearance, and hinders the penetration of light.

This is the first study that focuses on the diversity of macrobenthic decapod crustaceans in the estuarine floodplain surrounding Belém. Our objective was to analyze the possible effects of seasonality, sample site location, and trap size on catches. The potential effects of abiotic factors (temperature and salinity) on species richness and abundance were also analyzed.

\section{MATERIAL AND METHODS}

Belém is the capital of the state of Pará, and is located just $160 \mathrm{~km}$ south of the equator, between the Guamá River and the Guajará Bay. This area encompasses a large quantity of channels, rivers, streams, and tidal creeks, which form the city's released drainage system, and represent the principal route for the discharge of contaminants produced by the local industry and homes. 


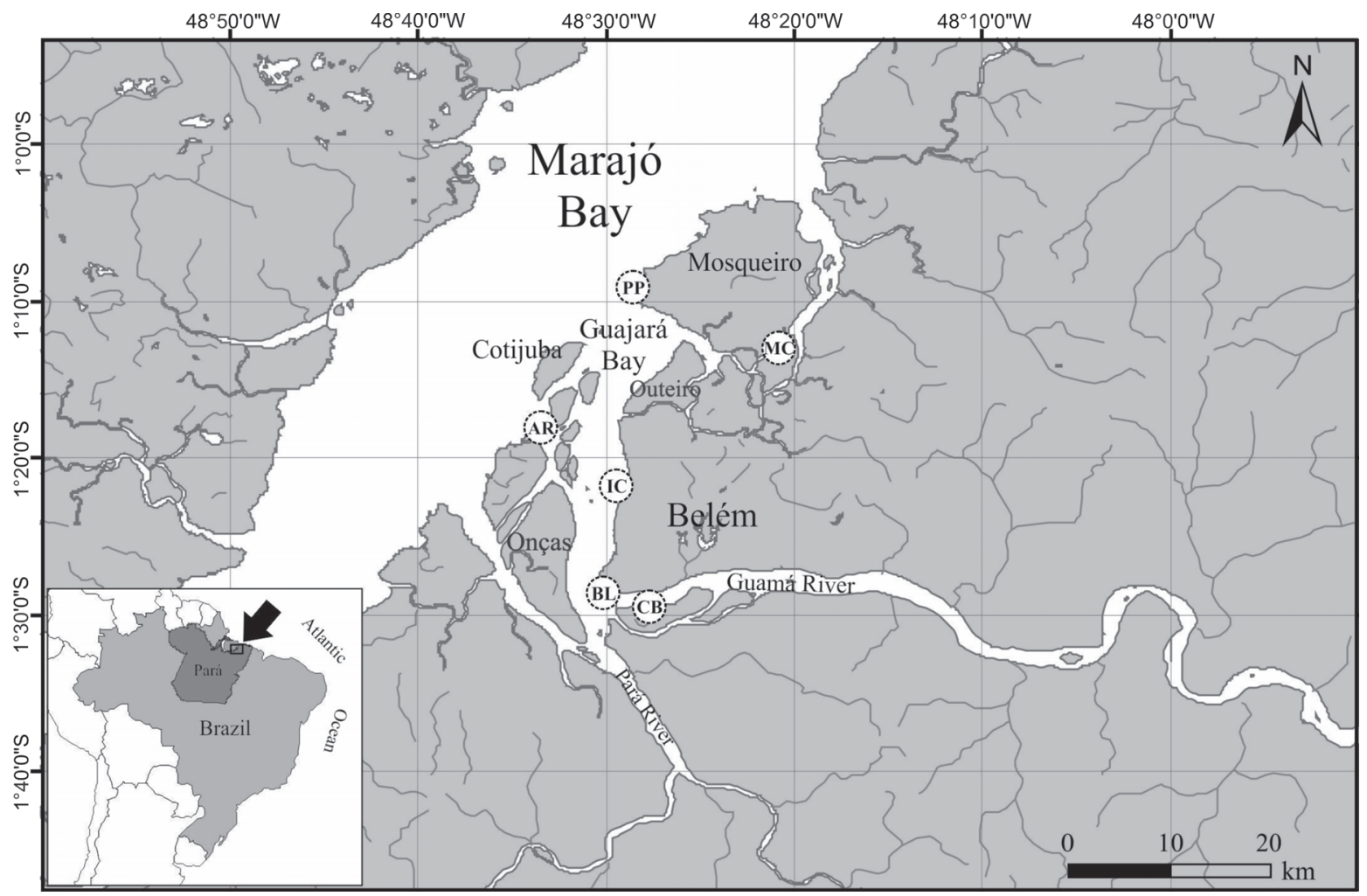

Figure 1. The study area, showing the sampling sites: (PP) Porto do Pelé, Mosqueiro Island; (MC) Marinhas Channel, Mosqueiro Island; (AR) Arapiranga Island; (IC) Icoaraci; (BL) Belém; (CB) Combu Island.

The present study focused on the Guajará Bay and the Mosqueiro Island, part of the Amazon River estuary, west of Belém (Fig. 1). The bay is narrow and elongated - delimited by three fluvial islands (Arapiranga, Cotijuba, and Onça), with Mosqueiro and Outeiro islands to the north and to the east, respectively - and flows seaward through the Marajó Bay (Moreira 1966). The Guajará Bay is the environment that is most affected by urban waste effluents anywhere in the Amazon basin. In Belém alone, there are approximately $30 \mathrm{~km}$ of drainage, some of which run through canals, where untreated sewage is discharged into the Guajará Bay.

The study area is characterized by strong tidal currents and by wind-blown waves that are powerful enough to provoke the mixing of the bay's waters and the resuspension of bottom sediments. The Guajará Bay is brackish at its lower reaches, due to the proximity to the Atlantic Ocean. However, the bay's salinity falls to zero during the course of the year, permitting the coexistence of both marine and, primarily, freshwater fish species (BARTHEM 1985).

The region's climate is hot and humid, with annual mean temperatures ranging from 23 to $32^{\circ} \mathrm{C}$, varying by only about two or three degrees during the course of the day. The mean relative air humidity is $85 \%$, with peaks of up to $100 \%$, par- ticularly between December and May, the local rainy season. The mean annual precipitation ranges from 2,500 to 3,000 $\mathrm{mm}$ (RAmos 2004). Based on rainfall, two periods are distinguishable - a dry season (from July to November) and a rainy season (from December to June).

The decapod fauna were surveyed at six sites (Fig. 1): Belém riverbank $\left(01^{\circ} 28^{\prime} \mathrm{S}, 48^{\circ} 26^{\prime} \mathrm{W}\right)$, Combu Island $\left(01^{\circ} 29^{\prime} \mathrm{S}\right.$, $\left.48^{\circ} 26^{\prime} \mathrm{W}\right)$, Icoaraci $\left(01^{\circ} 15^{\prime} \mathrm{S}, 48^{\circ} 32^{\prime} \mathrm{W}\right)$, Arapiranga Island $\left(01^{\circ} 15^{\prime} \mathrm{S}, 48^{\circ} 32^{\prime} \mathrm{W}\right)$, and two sites on Mosqueiro Island, Porto do Pelé $\left(01^{\circ} 09^{\prime} \mathrm{S}, 48^{\circ} 27^{\prime} \mathrm{W}\right)$ and Marinhas Channel $\left(01^{\circ} 10^{\prime} \mathrm{S}\right.$, $\left.48^{\circ} 19^{\prime} \mathrm{W}\right)$. These sites vary primarily in terms of their proximity to the Atlantic Ocean, with the more northerly points being subject to a greater influx of marine waters, and thus higher levels of salinity from July to November (dry season).

Specimens of decapods were sampled monthly from May 2006 to April 2007, with the aid of artisanal shrimp traps, known locally as matapis, which are widely used by the residents of local waterside human communities. Pairs of traps of three different sizes: Small (S) -10 x $38 \mathrm{~cm}$, Medium (M) -19 x $58.5 \mathrm{~cm}$ and Large (L) - $28 \times 82.5 \mathrm{~cm}$, were set at each sampling point (detailed description on Bentes et al. 2011). The two larger types of traps are used by local residents for shrimping, in particular to harvest Macrobrachium amazonicum (Heller, 1862). 
Six traps (two of each size) were set per month at each of the six sites over a 12 -month period, totaling 432 samples. The traps were set at low tide on the day prior to the new moon, and were baited with babaçu (Orbignya speciosa) flour wrapped in banana leaves and pieces of fish. The traps were retrieved at the subsequent low tide, after a 12-hour interval.

The temperature of the sub-superficial water was recorded with a mercury thermometer at the beginning and at the end of the sampling period. Simultaneously, sub-superficial water samples were obtained for the measurement of salinity, using an Atago optical refractometer. Monthly precipitation data were obtained from the National Water Agency (Ana 2007).

In the laboratory, the specimens collected were identified to the lowest taxonomic level, based on the reviews by Holthuis (1952) and Melo $(1999,2003)$. Species diversity, richness, and equitability (uniformity) at each site were estimated with the indices Shannon-Wiener, Margalef and Pielou, respectively, using the PRIMER ${ }^{\circledR} 6.0$ software (CLARKE \& WARWICK 1994).

The mean of temperature and salinity among sites were tested separately with ANOVA one-way. The median values of the Shannon-Wiener index were compared between the two seasons, and among sites and trap sizes, using the Friedman test (nonparametric analysis of variance). The Spearman's correlation coefficient was used to evaluate the possible relationship between abiotic variables (temperature and salinity) and species diversity (Shannon-Wiener). A 95\% significance level was adopted for all analyses.

\section{RESULTS}

Monthly precipitation in the study area varied between $33.7 \mathrm{~mm}$ in October 2006 (dry season) and $440.3 \mathrm{~mm}$ in May 2007 during the rainy season (Fig. 2).

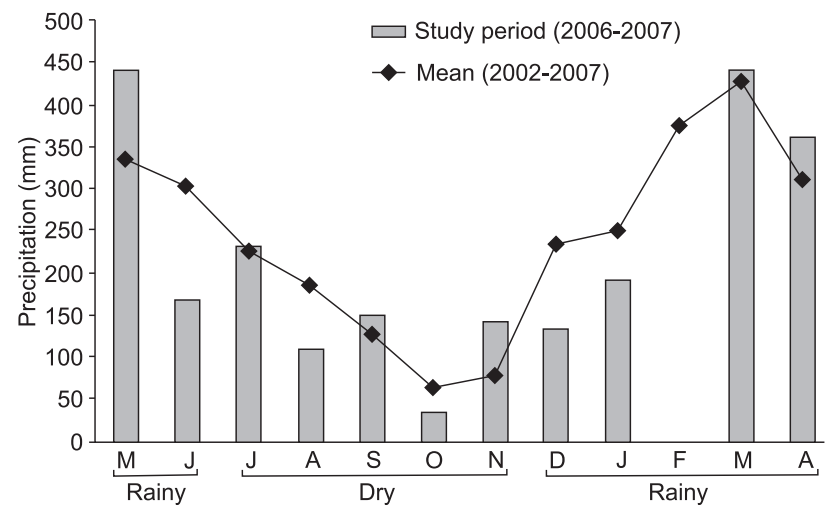

Figure 2. Monthly precipitation recorded at the Guajará Bay, Pará, Brazil, during the study period (2006-2007) compared with the mean values for the preceding five-year period (2002-2007). Source: ANA (2007). No data are available for February 2007, due to technical problems.
Salinity varied from zero - recorded at all six sites - to 8.0 in the Marinhas Channel. The lowest mean value (1.45 \pm 2.27) was recorded for Belém, whereas the Marinhas Channel returned the greatest mean, $3.16 \pm 3.37$ (Tab. I). Despite this variation, mean salinity did not vary significantly among months or sites $(\mathrm{F}=0.23, \mathrm{p}=0.94)$.

The water temperature varied from $23.5^{\circ} \mathrm{C}$ on Combu Island to $29.0^{\circ} \mathrm{C}$ in the Marinhas Channel, Mosqueiro Island, an amplitude of $5.5^{\circ} \mathrm{C}$ (Tab. I). The lowest mean temperature $\left(26.39 \pm 0.76^{\circ} \mathrm{C}\right)$ was recorded at the Arapiranga Island, and the highest $-27.84 \pm 0.44^{\circ} \mathrm{C}-$ in Icoaraci (Tab. I). The mean temperatures varied significantly among months. It was higher in Icoaraci, with values differing significantly $(\mathrm{F}=6.53, \mathrm{p}=$ 0.000072) from those recorded for Belém, Combu and Arapiranga islands, and Porto do Pelé.

A total of 6,793 decapod specimens were collected during the study period (Tab. II), with the largest catches obtained from the Arapiranga Island (22\% of the total), Icoaraci (21\%), and Combu Island (20\%). The smallest catches occurred in Belém (13\%), Porto do Pelé (13\%), and the Marinhas Channel (11\%). Overall, three families and 11 species of decapods were collected (Tab. II).

The largest number of specimens were collected in September, October and December 2006 (the months with the lowest precipitation), whereas the smallest number was collected in May (Fig. 3). The largest number of species (eight) was recorded in August and September, whereas the smallest (five) was recorded in June, November, February, March and April.

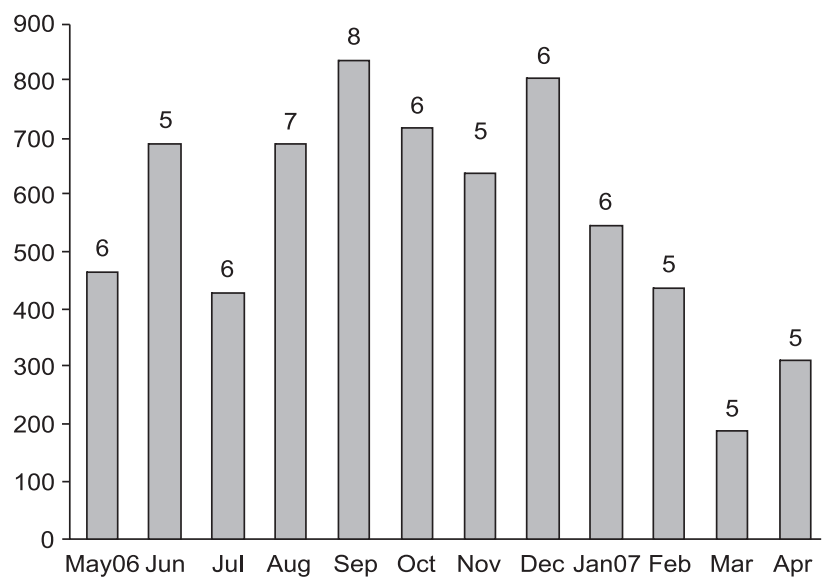

Figure 3. The number of decapod species (above each bar) and individuals ( $\mathrm{Y}$ axis) captured each month from the Guajará Bay, Pará, Brazil, from May 2006 to April 2007.

The highest number of specimens was captured at Arapiranga Island. The latter was the site with the fewest number of species recorded (4), together with Belém and the Marinhas Channel (3) (Tab. II). At the opposite extreme, the 
Table I. Mean salinity and temperature of the water recorded at the sites at the Guajará Bay (Pará, Brazil) monitored during the present study, from May 2006 to April 2007. (SD) Standard Deviation.

\begin{tabular}{|c|c|c|c|c|c|c|c|c|}
\hline \multirow{2}{*}{ Site } & \multicolumn{4}{|c|}{ Salinity } & \multicolumn{4}{|c|}{ Temperature $\left({ }^{\circ} \mathrm{C}\right)$} \\
\hline & Minimum & Maximum & Mean & SD & Minimum & Maximum & Mean & SD \\
\hline Porto do Pelé & 0.0 & 5.0 & 2.10 & 2.43 & 25.3 & 27.3 & 26.54 & 0.81 \\
\hline Marinhas Channel & 0.0 & 8.0 & 3.16 & 3.37 & 26.0 & 29.0 & 27.06 & 0.68 \\
\hline Arapiranga & 0.0 & 5.0 & 1.55 & 2.15 & 25.0 & 28.0 & 26.39 & 0.76 \\
\hline Icoaraci & 0.0 & 6.0 & 1.56 & 2.63 & 27.0 & 28.5 & 27.84 & 0.44 \\
\hline Belém & 0.0 & 5.0 & 1.45 & 2.27 & 24.5 & 29.0 & 26.41 & 0.75 \\
\hline Combu & 0.0 & 5.0 & 1.48 & 2.29 & 23.5 & 28.0 & 26.98 & 0.52 \\
\hline
\end{tabular}

Table II. Decapod crustacean species recorded during the present study, and the number of specimens collected at each of the sampling stations at the Guajará Bay area (Pará, Brazil) from May 2006 to April 2007. Site acronyms as in Figure 1.

\begin{tabular}{|c|c|c|c|c|c|c|c|}
\hline Species & $\mathrm{PP}$ & MC & AR & IC & $C B$ & $\mathrm{BL}$ & Total \\
\hline \multicolumn{8}{|l|}{ Palaemonidae } \\
\hline Macrobrachium amazonicum & 863 & 656 & 1333 & 1306 & 1147 & 830 & 6135 \\
\hline Macrobrachium surinamicum & 19 & 28 & 124 & 58 & 90 & 42 & 361 \\
\hline Macrobrachium carcinus & 1 & 0 & 30 & 0 & 1 & 0 & 32 \\
\hline Macrobrachium rosenbergii & 0 & 0 & 1 & 0 & 0 & 0 & 1 \\
\hline Macrobrachium sp. 1 & 0 & 0 & 0 & 1 & 0 & 0 & 1 \\
\hline Macrobrachium sp. 2 & 0 & 0 & 0 & 1 & 0 & 0 & 1 \\
\hline Macrobrachium sp. 3 & 1 & 0 & 0 & 0 & 0 & 0 & 1 \\
\hline Macrobrachium sp. 4 & 0 & 0 & 0 & 0 & 1 & 0 & 1 \\
\hline \multicolumn{8}{|l|}{ Portunidae } \\
\hline Callinectes bocourti & 21 & 79 & 0 & 33 & 0 & 0 & 133 \\
\hline \multicolumn{8}{|l|}{ Trichodactylidae } \\
\hline Sylviocarcinus devileii & 0 & 0 & 0 & 2 & 16 & 12 & 30 \\
\hline Sylviocarcinus pictus & 0 & 0 & 0 & 0 & 76 & 21 & 97 \\
\hline Total & 905 & 763 & 1488 & 1401 & 1331 & 905 & 6793 \\
\hline
\end{tabular}

Combu Island had the greatest number of species (6). Species diversity $\left(\mathrm{H}^{\prime}\right)$ was highest at Combu Island during the rainy season (0.87) and lowest at Porto do Pelé (0.22) during the dry season (Fig. 4). Equitability was highest in the Marinhas Channel (0.45) during the rainy season and lowest (0.11) at Porto do Pelé during the dry season. Species richness was highest at Combu Island and Belém (0.75) during the rainy season and lowest at Icoaraci $(0.29)$ during the same period. A small variation between the dry and the rainy season was found at Porto do Pelé and Marinhas Channel sites (both near to ocean). There was low variation in the three indices at the latter site. No significant variation in relation to season or site was recorded for any of these indices $\left(\mathrm{d}\right.$ : Fr $=0.67, \mathrm{p}=0.41 ; \mathrm{J}^{\prime}: \mathrm{Fr}=2.67, \mathrm{p}=$ $0.10 ; \mathrm{H}^{\prime}: \mathrm{Fr}=2.66, \mathrm{p}=0.10$ ).

Considerable variation was also observed in the calculated indices when considering the different trap sizes (Fig. 5). The highest equitability $\left(\mathrm{J}^{\prime}\right)$ and diversity $\left(\mathrm{H}^{\prime}\right)$ values were recorded for the large traps in Belém (0.98 and 1.97, respectively), whereas species richness (d) was highest at Combu Island (0.97), also in the large traps. By contrast, the lowest values were almost invariably recorded for the medium-sized traps. The lowest $d$ values (0.15) were recorded at the Arapiranga Island, in both small and medium traps, whereas the lowest $\mathrm{J}^{\prime}$ and $\mathrm{H}^{\prime}$ values were recorded in medium-sized traps at Porto do Pelé $(0.04)$ and Belém $(0.20)$, respectively. None of the differences among trap sizes were significant to $\mathrm{d}(\mathrm{Fr}=4.08, \mathrm{p}=0.13)$ and $\mathrm{J}^{\prime}(\mathrm{Fr}=2.33, \mathrm{p}=0.31)$. The diversity was significantly higher in large than in the medium sized matapis $(\mathrm{Fr}=7.0, \mathrm{p}=0.03)$.

There was a significantly positive correlation between the number of specimens captured each month and salinity $(\mathrm{r}=$ $0.66, \mathrm{p}<0.05)$, although this was due primarily to the contribution of M. amazonicum $(r=0.76, p<0.05)$. None of the other species were significantly correlated with salinity, although this might have been due to small sample size in most cases $(\mathrm{n}<$ 400 all along). The number of species collected per month did not vary significantly in relation to salinity $(r=0.43, p>0.05)$. No clear relationship was found between temperature and number of either species or specimens. 

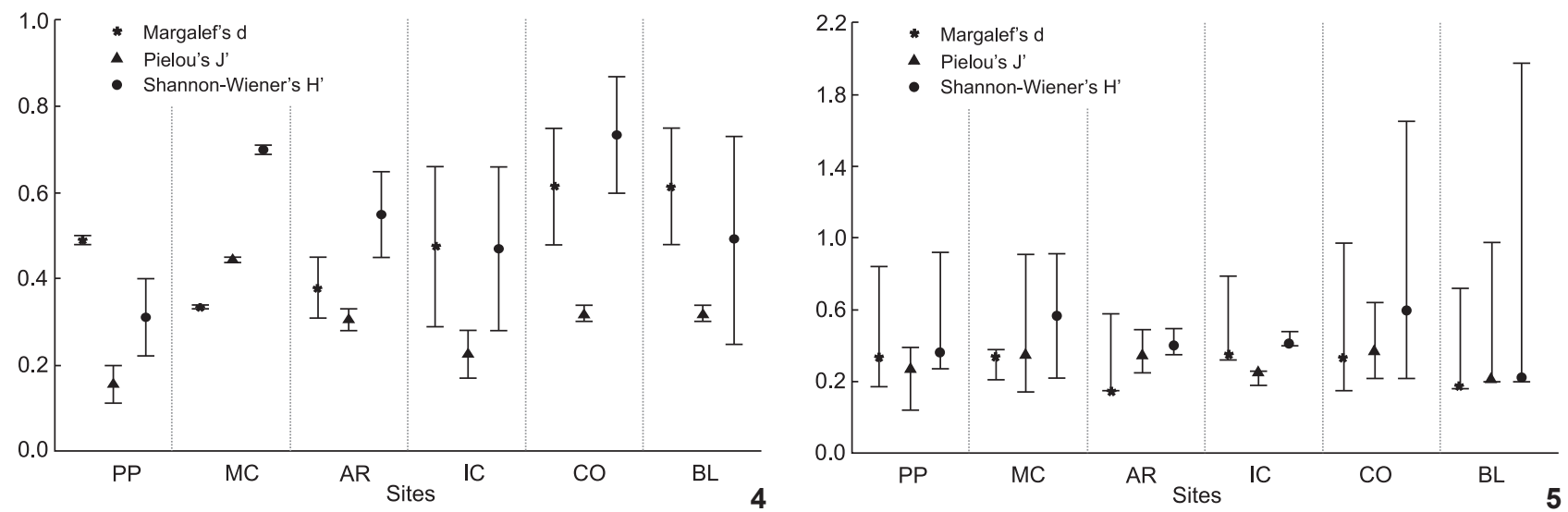

Figures 4-5. Community indices recorded by site during the present study (May 2006 to April 2007) at the Guajará Bay, Pará, Brazil: (4) by season; (5) by trap size.

\section{DISCUSSION}

Precipitation values recorded in the study area during the study period were similar to those recorded during the preceding five-year period (2002-2006), with the exception of June 2006, during which rainfall was little more than half the average (167.00 mm vs. $301.42 \mathrm{~mm}$ ). Throughout most of the state of Pará, the rainy season normally begins in December and ends in July (Moraes et al. 2005), with an annual mean of 2,300-2,800 mm.

Temperature does not appear to have any major influence on the diversity of decapods in the region, although there is relatively little variation in this parameter in the equatorial zone. The variation in salinity can be accounted for by the fluctuations in river discharge, precipitation, and tidal currents. The Guajará Bay can be considered virtually as a river during almost all year, due to discharge from the Amazon River, which effectively inhibits the advance of the saline wedge mainly during the rainy season. In the present study, salinity varied from zero to eigth, with the highest values being recorded at the Marinhas Channel, which is the site most influenced by the mass of marine waters at the mouth of the Amazon estuary. The highest salinity (8.0) was recorded in October 2006, the month with the lowest precipitation $(61.9 \mathrm{~mm})$. The results of the present study re-emphasize the influence of salinity levels on the distribution of the decapod species found in this region, which would account for the occurrence of freshwater crab species - Sylviocarcinus devileii H. Milne-Edwards, 1853 and Sylviocarcinus pictus (MilneEdwards, 1853) -, in particular at Belém and Combu Island where salinity was virtually null throughout the year - as well as the presence of the marine-estuarine genera Uca Leach, 1814 and Callinectes Stimpson, 1860 on Mosqueiro Island (pers. obs.).

Prior to the present study, a total of 164 species of macrobenthic decapod crustaceans had been recorded in Pará (Melo 1999, 2003). These species belong to the infraorders Anomura (24 species), Brachyura (115), Caridae (12), Palinura (4), Sergestoidea (2), Axiidea (4) and Gebiidae (3). Of these infraorders, only Brachyura and Caridae were collected in the present study, reflecting the predominantly freshwater habitats of the surveyed area. The infraorders Anomura, Palinura, Axiidea, and Gebiidae include estuarine-marine crustaceans, whereas the Sergestoidea is composed of freshwater, estuarine and marine species, most of which are planktonic. Of the 11 species collected during the present study, eight are palaemonids $-M$. amazonicum, Macrobrachium surinamicum Holthuis, 1948, Macrobrachium carcinus (Linnaeus, 1758), Macrobrachium rosenbergii (De Man, 1879), Macrobrachium spp. (1-4) -, one is a portunid - Callinectes bocourti A. Milne-Edwards, 1879 -, and two are trichodactylids $-S$. devileii and $S$. pictus. All of these species have been recorded previously in Pará, although M. rosenbergii is an exotic species, which is thought to have been introduced into the region by escaping from local shrimp-farming tanks.

There was a tendency for increased abundance and species richness in the dry season (August-November), especially at Icoaraci, Arapiranga and Combu islands. There was also a marked tendency for the larger traps - known locally as "mundurus" to capture a higher diversity of crustaceans. The only significant pattern recorded was a correlation between salinity and the abundance of M. amazonicum, indicating the need for the investigation of additional abiotic and biotic variables, such as vegetation and detritus, which may influence the local diversity and abundance of decapods. While the diversity of macrobenthic decapods was relatively low in the study area, there was a marked predominance of $M$. amazonicum, which is a species of considerable economic and cultural importance to the subsistence and income of local waterside communities.

\section{ACKNOWLEDGMENTS}

We are grateful to Morgana C. de Almeida, Roberto V. Espírito-Santo, Antônio S. Carvalho, Priscila A. Carmona, Allan J.S. de Jesus, Charles M. Oliveira, Gilberto Meireles, Robson Silva, Leocyvan Nunes, Renata Bentes, Beatriz Bentes, and Emílio Bentes 
for their assistance during the collecting, transportation, and processing of specimens, and also to local shrimpers João Rosa ("Parau"). Stephen Ferrari translated the original text into English. The project was financed by the Brazilian National Research Council (CNPq) through concession number 553125/2005-2 and by the Pró-Reitoria de Pesquisa/Universidade Federal do Pará (PROPESP/UFPA) and Fundação de Amparo e Desenvolvimento da Pesquisa (FADESP) and through a graduate stipend to the second author. The collection of specimens was authorized by the Brazilian Environment Institute (IBAMA), through special license 02018.00729/06-36. We are grateful to the referee for a number of helpful suggestions for improvement in the article.

\section{LITERATURE CITED}

Arruda, D.B. \& F.A. Abrunhosa. 2011. Redescription of megalopa and juvenile development of Pachygrapsus gracilis (Saussure, 1858) (Decapoda: Grapsidae) from the Amazon region, reared in the laboratory. Zoologia 28 (4): 465-478. doi: 10.1590/S1984-46702011000400008

ANA. 2007. Agência Nacional das Águas. Brasília. Available online at: http://www.ana.gov.br [Accessed: 01/XII/2007].

Barros, M.P. \& F.R. Pimentel. 2001. A fauna de Decapoda (Crustacea) do Estado do Pará,Brasil: lista preliminar de espécies. Boletim do Museu Paraense Emilio Goeldi, Série Zoologia, 17 (1): 15-41.

Barthem, R.B. 1985. Ocorrência, distribuição e biologia dos peixes da baía de Marajó, estuário amazônico. Boletim do Museu Paraense Emílio Goeldi 2 (1): 49-69.

Bentes, B.S.; J.M. Martinelli; D.V. Cavalcante; L.S. Silva; M.C. Almeida \& V.J. IsaAC. 2011. Spatial distribution of the Amazon River shrimp Macrobrachium amazonicum (Heller, 1862) (Decapoda, Caridea, Palaemonidae) in two perennial creeks of an estuary on the northern coast of Brazil (Guajará Bay, Belém, PA). Brazilian Journal of Biology 71 (4): 925-935.

Clarke, K.R. \& R.M. Warwick. 1994. Change in marine communities: an approach to statistical analysis and interpretation. Plymouth, Natural Environmental Research Council, $144 \mathrm{p}$.

CinTRA, I.H.A.; K.C.A. Silva; A.P.M. Muniz. 2003a. Ocorrência de Macrobrachium rosenbergii (De Man, 1879) em áreas estuarinas do Pará (Crustacea, Decapoda, Palaemonidae). Boletim Técnico-Científico do CEPNOR 3 (1): 219-227.

Cintra, I.H.A.; K.C.A. Silva; M. Ramos-porto; G.F.S. Viana. 2003 b. Siris capturados durante pescarias experimentais para o Programa REVIZEE/Norte (Crustacea, Brachyura, Portunidae). Boletim Técnico-Científico do CEPNOR 3 (1): 53-75.

CorrêA, A.B. \& J.M. Martinelli. 2009. Composição da população do camarão-rosa Farfantepenaeus subtilis (Pérez-Farfante, 1936) no estuário do Rio Curuçá, Pará, Brasil. Revista Científica da UFPA 7 (1): 1-18.

HeNDRICKX, M.E. 1995. Checklist of brachyuran crabs (Crustacea: Decapoda) from the eastern tropical Pacific. Bulletin de
l'Institut Royal des Sciences Naturelles de Belgique, Biologie 65: 125-150.

Holthuis, L.B. 1952. A general revision of the Palaemonidae (Crustacea, Decapoda, Natantia) of the Americas. II. The subfamily Palaemoninae. Allan Hancock Foundation Publications. California: Occasional Paper 12: 1-396.

Maciel, C.; L. Quadros; F.A. Abrunhosa; S. Bastos; H. Schneider \& M.I. SAMPAIO. 2011. Occurrence of the Indo-Pacific freshwater prawn Macrobrachium equidens Dana 1852 (Decapoda, Palaemonidae) on the coast of Brazilian Amazonia, with notes on its reproductive biology. Anais da Academia Brasileira de Ciências 83: 533-544.

Magalhães, C. 1999. Crustáceos Decápodos, p. 143-287. In: D. Ismael; W.C. Valenti \& C. Magalhães. 2003. Famílias Pseudothelphusidae e Trichodactylidae. In: G.A.S. Melo (ED.). Manual de identificação dos Crustacea Decapoda de água doce do Brasil. São Paulo, Edições Loyola.

Magris, R.A.; G. Bond-Buckup; C. Magalhães; F.L. Mantelatto, J.W. Reid; L.M.A.E. Loureiro; P.A. Coelho; W. Santana; L. Buckup; S.S. DA Rocha; S.L.S. Bueno; M.A.A. Pinheiro; F. D'IncaO; C.T.C. Ivo; J.D. Neto; E.S. Rodrigues; P.B. Araujo; H.B. Júnior \& L.F.A. DUARTE. 2010. Quantification of extinction risk for crustacean species: an overview of the National Red Listing process in Brazil. Nauplius 18 (2): 129-135.

Melo, G.A.S. 1999. Infraordem Brachyura. Siris e caranguejos: espécies marinhas e estuarinas, p. 415-485. In: L. BucKup \& G. Bond-BUCKUP (Eds). Os crustáceos do Rio Grande do Sul. Porto Alegre, UFRGS.

Melo, G.A.S. 2003. Manual de identificação dos Crustacea Decapoda de água doce do Brasil. São Paulo, Edições Loyola, 430p.

Moraes, B.C.; J.M.N. Costa; A.C.L. Costa \& M.H. Costa. 2005. Variação espacial e temporal da precipitação no estado do Pará. Acta Amazonica 35 (2): 207-214.

Moreira, E. 1966. Belém e sua expressão geográfica. Belém, Imprensa Universitária, 212p.

Nevis, A.B.; J.M. Martinelli; A.S.S. Carvalho \& V.J. Issac. 2009. Abundance and spatial-temporal distribution of the family Portunidae (Crustacea, Decapoda) in the Curuçá estuary on the northern coast of Brazil. Brazilian Journal of Aquatic Science and Tecnology 23 (1): 71-79.

Oliveira, D.B.; D.C. Silva \& J.M. Martinelli. 2012a. Density of larval and adult forms of the burrowing crustaceans Lepidophthalmus siriboia (Callianassidae) and Upogebia vasquezi (Upogebiidae) in an Amazon estuary, northern Brazil. Journal of the Marine Biological Association of the United Kingdom 92 (2): 295-303. doi: 10.1017/ S002531541100097X.

Oliveira, D.B.; J.M. Martinelli \& F.A. Abrunhosa. 2012 b. Description of early larval stages of Upogebia vasquezi (Gebiidea: Upogebiidae) reared in laboratory. Journal of the Marine Biological Association of the United Kingdom 92 (2): 335-342. doi: 10.1017/S0025315411000956. 
Pires, M.A.B.; F.A. Abrunhosa \& C. Maciel. 2008. Early larval development of Alpheus estuariensis (Crustacea: Caridea) from the Amazon Region. Revista Brasileira de Zoologia 25 (2): 199-205. doi: 10.1590/S0101-81752008000200006

Ramos, J. 2004. Poluição e contaminação da orla de Belém/PA, p. 121-148. In: S. Uhly \& E.L. SouzA (Eds). A questão da água na grande Belém. Belém, Casa de Estudos Germânicos, UFPA.

Rocha, S.S. \& S.L.S. Bueno. 2004. Crustáceos decápodes de água doce com ocorrência no Vale do Ribeira de Iguape e rios costeiros adjacentes, São Paulo, Brasil. Revista Brasileira de Zoologia 21 (4): 1001-1010. doi: 10.1590/S010181752004000400038

Silva, K.C.A.; C.L. Cardooso; I.H.A. Cintra \& G.S.L. Pantaleão. 2005. Siris do Gênero Callinectes Stimpson, 1860 (Decapoda, Portunidae) em estuários do Nordeste paraense. Boletim Técnico-Científico do CEPNOR 5: 25-42.

Silva, K.C.A.; I.L.S. Ferreira; C.T.C. Ivo; M.V.L.F. Araújo; A.G.C.M. Klautau \& I.H.A. Cintra. 2009. Aspectos reprodutivos do caranguejo-uçá Ucides cordatus (Linnaeus, 1763) na reserva extrativista marinha Mãe Grande de Curuçá, Pará, Brasil. Boletim Técnico-Científico do CEPNOR 9: 9-23.

Silva, L.S.; J.M. Martinelli; M.A.P. Ferreira; R.M. Rocha. 2012. Gonadal development in the freshwater crab Sylviocarcinus pictus (Brachyura: Trichodactylidae). Anais da Academia Brasileira de Ciências 84 (2): junho.

Simith, D.J.; K. Diele \& F.A. Abrunhosa. 2010. Influence of natural settlement cues on the metamorphosis of fiddler crab megalopae, Uca vocator (Decapoda: Ocypodidae). Anais da Academia Brasileira de Ciências 82: 313-321.

Simith, D.J.; A. Souza; C. Maciel; F.A. Abrunhosa \& K. Diele. 2011. Influence of salinity on the larval development of the fiddler crab Uca vocator (Ocypodidae) as an indicator of ontogenetic migration towards offshore waters. Helgoland Marine Research 66 (1): 77-85.

Viana, G.F.S.; M. Ramos-PORTO; M.D.C.F. SANTOS; K.C.A. SiLVA; I.H.A. Cintra; E. Cabral; M.F.A. Torres \& F.D. Acioli. 2003. Caranguejos coletados no Norte e Nordeste do Brasil durante o Programa REVIZEE (Crustacea: Decapoda: Brachyura). Boletim Técnico Científico do CEPENE 11 (1): 117-144.

Submitted: 23.VIII.2011; Accepted: 21.III.2012.

Editorial responsibility: Paulo da Cunha Lana 